\title{
The Effect of Spraying with Two Different Sources of Calciumin Vegetative Growth Characteristics and Yield of Potato
}

\author{
*N. J. K.Al-Aamry, M. A. Hussein, A.H.Mahmood \\ Department of Horticulture and Landscape Gardening, College of Agriculture, University of Baghdad, Iraq \\ Corresponding Author: N. J. K. Al-Aamry
}

\begin{abstract}
A field experiment was conducted in Research Station A - College of Agriculture-University of Baghdad, during the fall season of 2015, which attempts to study the effect of spraying calcium of two different sources, mineral and organic:aliquid mineral fertilizer (Fosfital calcium) atthree levels $\left(2.5,5,7.5 \mathrm{ml} . \mathrm{L}^{-1}\right)$ and the a liquid organic fertilizer (Polixal) withthree levels $\left(2.5,5,7.5 \mathrm{ml} . \mathrm{L}^{-1}\right)$ beside control treatment in the vegetative growth and production indicators of Burren potato variety using Randomized Complete Block Design with three replications. The experiment results demonstrated that spraying with the calcium organic source enhancedvegetative growth indicators as represented in the number of leaves and the dry weight of the vegetative growth, wherenon-significant in number of air stems indicator.However,calcium from organic source also gave a significant effect inthe tubers production and the crop indicators as represented by the dry matter percentage, tubers content of $\mathrm{N}, \mathrm{Ca}$, protein, starch, activity of a-amylase and peroxidase enzymes, marketable plant yield, number of marketable tubers, and the total marketable yield. It was also found that spraying with mineral calcium source gave the highest content of $P$ and $K$ in yielding tubers in compare to control treatment which gave the lowest values of these indicators. These results showed the significance of foliar application with calcium from organic source and it's positive effectin improving the crop quality, nutritional content andreducing negative effects in the environment which result from using the mineral sources.
\end{abstract}

Keywords:calcium, $\alpha$-amylase, peroxidase, potato.

\section{Introduction}

Potato Solanumtuberosum is considered one of the vegetative crops that can exhaust the soil, thus, it requires during it's different growth stages such large amounts of major nutritional elements. For the purpose of achieving the best advantage possible of using fertilizers, it is often suggested that organic and phosphate fertilizers are used, in addition to nitrogen fertilizers, known for their being key to stimulate vegetative growth of potato before tubers formation(Bores et al., 2011).

Several of the nutritional elements including calcium found in the soil or added to it, these nutritional elements are subject to loss processes by washing or fixation due to being affected by the level ofpH soil, in addition to the high temperature climate as well as the high content of lime and mud. Generally, lack of calcium is rare in Iraqi soils, although calcium has an issue of transference from the soil to the plant parts and between the various plant parts due to its slow motion inside the plant, in addition to being subjected to loss or fixation (Abu Dahi and Al-Younis,1988 and Ali, 2012) which can negatively affect the nutritional requirements for the plant and consequently a decrease in the indicators of quantity and quality, hence the significance of foliar nutrition for the plant as an important and effective methods to save for a nutrition requirements for plant.

\section{Literature Review}

Observers of the reality to use fertilizers in Iraq may probably notice that calcium is less used in fertilizing processes especially the foliar fertilizing processes. However, calcium play a role in improving the crop growth and quality due to increase the dry matter through maximizing the efficiency of $\mathrm{CO}_{2}$ fixation and its significance in the retention of the permeability and activity of cell membranes (Al-Sahaf, 1989a).

Al-Dobybi (2003) found that potatoplants of were responded to foliar fertilization with a combination of $\mathrm{K}+\mathrm{Ca}+\mathrm{B}$ elements and enhancement the quality characteristics for the tubersincreasing its economic value. Al-Mharib (2008) found the use of the various calcium fertilizers (nitrate and sulphate) with the optimal level was gave a highest crop marketable and the highest total yield. The plant works to produce enzymes to continue and exist and formation of a number of necessary compounds to accomplish that. These productive enzymes can be secretedextracellularor can remain secreting endocellulary(Priest, 1984). One of these enzymes is the peroxidase found in plant cell walls and formed in cytoplasm (Harris, 1978). The increasedactivity of this enzyme is considered one of the plant response forms in the case of nutritional components abundance, thus, 
nutrients especially these rich in calcium can have a stimulated effect (Yoon et al., 1993). Although $\alpha$-amylase enzyme spreads in various parts of the plant tissues, it is found more in fibers which rich with starch, concentrated in the leaves in the chloroplast (Braun and Shtelzer, 1994). Sadik (2007) found that the highest activity rate of these two enzymes is at the development completion of the fruits and tubers and the activity generically changes according to the development stages of tubers growth.

Recently, several agricultural practices have been adopted particularly balanced fertilization for chemical fertilizers and resorting to use organic fertilizers instead, whether these are liquid and manufactured or as resolved animal remains with the purpose of making sure to obtain agrarian products that are highly productive, of a high quality and reducing the harmful effects of the environment (Chen et al., 2006).

Al-Ajeel and Al-Hasnawi (2011) shows that spraying two cultivars of potato (Aladin and Burren) with different levels of liquid fertilizer "Liq. Humus" have a significant effect by maximizing the crop quantity and the percentages of the elements of nitrogen, potassium, phosphor, dry matter, vitamin C, and nitrate concentrations in tubers. Given the fact that potato has both nutrient and manufacturing importance in the nutrition system as it is the main source for starch and protein, its tubers have big amounts of vitamin $\mathrm{C}$ and the various mineral salts such as potassium and phosphor and other elements (Matlob et al.,1989). However, the importance of calcium element nutrition in putting-up production characteristics and the quality of the crop produced via its physiological effect in stimulating the formation of plant cells walls, maintaining their density and firmness, regulating permeability, facilitating the movement and transversionof nutrients and carbon assimilation products and the effect it in auxineformation in the plant (David, 2007).The aim of this experiment was usage a various levels of nutrients whether of a mineral source or organic added by being sprayed in the collective vegetative of the potato plants in order to obtain the optimal level possible to maximize the production and increase vegetativegrowth.

\section{Materials and Methods}

The experiment was conducted in the fieldA, College of Agriculture,University of Baghdad during the fall season of 2015. Potato tubers cv. Burren(class Elite) wasplanted in order to study the effect of foliar applicationof two types of calcium fertilizers: mineral and organicon vegetative growth and yield of potato plants. Tubers were planted on September $29^{\text {th }}, 2015$ on rows spaced $75 \mathrm{~cm}$ in between and $30 \mathrm{~cm}$ between plants on both sides of the row in a way that each experimental unit will consisted of 20 plants.

\section{Experiment Factors}

The factors studied included using mineral source for calcium (fosfital calcium) which contains 5\% $\mathrm{CaO}$ and $14.37 \%$ of $\mathrm{P}_{2} \mathrm{O}_{2}$ at three levels : $2.5 \mathrm{ml} . \mathrm{L}^{-1}(\mathrm{Ca} 1), 5 \mathrm{ml} . \mathrm{L}^{-1}(\mathrm{Ca} 2), 7.5 \mathrm{ml} . \mathrm{L}^{-1}(\mathrm{Ca} 3)$ and organic source of calcium (polixal) which contains $10.6 \% \mathrm{CaO}$ and $58.3 \%$ total organic matter in dry matter with three levels : 2.5 $\mathrm{ml} . \mathrm{L}^{-1}(\mathrm{Ca} 4)$, $5 \mathrm{ml} . \mathrm{L}^{-1}(\mathrm{Ca} 5)$, 7.5 $\mathrm{ml}^{-\mathrm{L}^{-1}}(\mathrm{Ca} 6)$ beside control treatment (Ca7). The agricultural processes were carried out as recommended by (Matlob et al.,1989).

All plants were sprayed three times at different stages of growth (i.e. 40 days after emergence and 15 days between spray there after). After 14 days of the third spray a random sample of five plants were taken from each experimental unit to determine the growth characteristics of potato plants (number of leaves, air stems and dry weight of vegetative growth). At the harvesting time in Jan. $18^{\text {th }} 2016$ a random samples from each experimental unit was selected to obtain tubers characteristics (dry matter, content of protein and starch based on dry matter) according to the methods described by (A.O.A.C.1970). Nitrogen, phosphorus, potassium and calcium percentage using the methods by (John , 1970 and Al-Sahaf,1989a).Fresh tubers samples were used to determine the activity of $\alpha$-amylase enzymes according to (Miller,1959) and peroxidase enzymes usingthe motheds described by (Nezih,1985). The yield characters (marketable plant yield, number of marketable tubers and total marketable yield).The experiment was conducted by using Randomized Complete Blocks Design (R.C.B.D.) and the results were analyzed according to GenStat (2013) statistical analysis program and the means were compared using least significant difference (L.S.D.) at 0.05 probability level (El-Sahooki and Wahaib , 1990)

\section{Results and Discussions}

The results from table 1 show the significant effect of spraying treatments from the organic source in both levels 5 and $7.5 \mathrm{ml} . \mathrm{L}^{-1}$. Organic source (polixal)when applied with highest level $7.5 \mathrm{ml} . \mathrm{L}^{-1}$ (Ca6) gave a higher number of leaves 73.0 leaf.plant ${ }^{-1}$ in comparisons withlowest numberof leaves which recorded in plants of control treatment (Ca7) 26.0 leaf.plant ${ }^{-1}$. However, spraying with mineral and organic sources gave no significant effect in number of air stems. While the spraying with polixal in level $5 \mathrm{ml} . \mathrm{L}^{-1}(\mathrm{Ca} 5)$ gave a higher dry weight of vegetative growth compare to control treatment $(\mathrm{Ca} 7)$ which gave a lowest value for this indicator reach to 34.6 and $16.28 \mathrm{~g}$ respectively.

Table1: Effect of spraying with two different sources of calcium in vegetative growth indicators 
The Effect of Spraying with Two Different Sources of Calcium in Vegetative Growth Characteristics

\begin{tabular}{|c|c|c|c|}
\hline Treatments & $\begin{array}{c}\text { number of leaves } \\
\text { (leaf. plant }^{-1} \text { ) }\end{array}$ & $\begin{array}{c}\text { number of air } \\
\text { stems(stem.plant }\end{array}$ & $\begin{array}{c}\text { Dry weight of vegetative } \\
\text { growth } \\
\text { (g) }\end{array}$ \\
\hline Ca1 & 65.7 & 3.67 & 28.40 \\
\hline Ca2 & 67.3 & 3.33 & 31.17 \\
\hline Ca3 & 52.7 & 3.67 & 31.70 \\
\hline Ca4 & 59.7 & 4.00 & 32.17 \\
\hline Ca5 & 70.0 & 4.00 & 34.60 \\
\hline Ca6 & 73.0 & 3.67 & 30.87 \\
\hline Ca7 & 26.0 & $\mathbf{2 . 6 7}$ & $\mathbf{1 6 . 2 8}$ \\
\hline L.S.D.5\% & 29.63 & N.S & 4.51 \\
\hline
\end{tabular}

The results in table 2 indicate that there was a significant effect of spraying treatments with two calcium source in all tubers indicators. However,organic source when applied at $5 \mathrm{ml} . \mathrm{L}^{-1}(\mathrm{Ca} 5)$ gave a highest percentage of dry matter, $\mathrm{Ca}$ and $\mathrm{N}$ contents , protein and starch in tubers reach to $14.68 \%, 2.06 \%, 0.37 \%$, $12.87 \%$ and $9.09 \%$ respectively compare to control treatment $(\mathrm{Ca} 7)$ which gave the lowest values for these indicators reaching to $7.44 \%, 1.44 \%, 0.12 \%, 9.00 \%$ and $2.65 \%$ respectively. While the activity of $\alpha$-amylase and peroxidase enzymes were significant affected by spraying with organic sourceat $7.5 \mathrm{ml}^{-\mathrm{L}^{-1}}(\mathrm{Ca} 6)$ when compared to control treatment $(\mathrm{Ca} 7)$ which reach to $1.71,0.33,0.37$ and 0.30 absorbing unit respectively. It also noticed that spraying with mineral calcium source (fosfital calcium) at $2.5 \mathrm{ml} . \mathrm{L}^{-1}$ (Ca1) gave a significant effect in content of $\mathrm{P}$ and $\mathrm{K}$ in tubers which reach to $0.29 \%$ and $1.87 \%$ respectively in comparison with plants of control treatment (Ca7) which gave the lowest content of these indicators reach to $0.02 \%$ and $0.04 \%$ respectively.

Table2: Effect of spraying with two different sources of calcium in yielding tubers indicators

\begin{tabular}{|c|c|c|c|c|c|c|c|c|c|}
\hline $\begin{array}{c}\text { Treatmen } \\
\text { ts }\end{array}$ & $\begin{array}{c}\text { Dry } \\
\text { matte } \\
\text { r \% }\end{array}$ & $\begin{array}{c}\mathbf{N} \\
\text { content } \\
\%\end{array}$ & $\begin{array}{c}\mathbf{P} \\
\text { content } \\
\%\end{array}$ & $\begin{array}{c}\mathbf{K} \\
\text { content } \\
\%\end{array}$ & $\begin{array}{c}\text { Ca content } \\
\%\end{array}$ & $\begin{array}{c}\text { Protein } \\
\text { content } \\
\%\end{array}$ & $\begin{array}{c}\text { Starch } \\
\text { content } \\
\%\end{array}$ & $\begin{array}{l}\text { a-amylase } \\
\text { enzyme } \\
\text { activity } \\
\text { (absorbing } \\
\text { unit) }\end{array}$ & $\begin{array}{l}\text { POD enzyme } \\
\text { activity } \\
\text { (absorbing } \\
\text { unit) }\end{array}$ \\
\hline Ca1 & 9.51 & 1.59 & 0.29 & 1.87 & 0.16 & 9.94 & 4.48 & 1.16 & 0.03 \\
\hline $\mathrm{Ca2}$ & 10.98 & 1.71 & 0.23 & 1.71 & 0.15 & 10.71 & 5.79 & 1.14 & 0.03 \\
\hline Ca3 & 10.77 & 1.74 & 0.25 & 1.54 & 0.15 & 10.90 & 5.61 & 1.16 & 0.03 \\
\hline Ca4 & 13.08 & 1.53 & 0.28 & 1.27 & 0.31 & 9.60 & 7.67 & 1.28 & 0.04 \\
\hline Ca5 & 14.68 & 2.06 & 0.23 & 1.23 & 0.37 & 12.87 & 9.09 & 1.59 & 0.12 \\
\hline Ca6 & 10.62 & 1.81 & 0.23 & 1.29 & 0.25 & 11.31 & 5.48 & 1.71 & 0.33 \\
\hline Ca7 & 7.44 & 1.44 & 0.17 & 0.30 & 0.12 & 9.00 & 2.65 & 0.58 & 0.01 \\
\hline L.S.D. & 1.94 & 0.23 & 0.02 & 0.04 & 0.06 & 1.49 & 1.73 & 0.37 & 0.03 \\
\hline
\end{tabular}

The results from table 3 show that foliar application of calcium from organic source at $5 \mathrm{ml} . \mathrm{L}^{-1}(\mathrm{Ca} 5)$ gave the highest values in all yield indicators (marketable plant yield, number of marketable tubers and total marketable yield) which reach to $1012 \mathrm{~g}, 11.67$ tuber.plant $^{-1}$ and 23.33 ton. $\mathrm{H}^{-1}$ respectively compared to control treatment $(\mathrm{Ca} 7)$ which recorded the lowest values in these indicators reach to $551 \mathrm{~g}, 3.67$ tuber.plant $^{-1}$ and 14.30 ton. $\mathrm{H}^{-1}$ respectively.

Table3: Effect of spraying with two different sources of calcium in yield indicators

\begin{tabular}{|c|c|c|c|}
\hline Treatments & $\begin{array}{c}\text { marketable plant yield } \\
(\mathrm{g})\end{array}$ & $\begin{array}{c}\text { number of marketable } \\
\text { tubers (tuber.plant }{ }^{-1} \text { ) }\end{array}$ & $\begin{array}{c}\text { total marketable yield } \\
\left(\text { ton. } H^{-1}\right)\end{array}$ \\
\hline Ca1 & 764 & 8.67 & 20.00 \\
\hline $\mathrm{Ca} 2$ & 641 & 7.00 & 18.88 \\
\hline Ca3 & 554 & 5.33 & 17.20 \\
\hline Ca4 & 965 & 9.00 & 21.29 \\
\hline Ca5 & 1012 & 11.67 & 23.33 \\
\hline Ca6 & 747 & 8.67 & 21.43 \\
\hline Ca7 & 551 & 3.67 & 14.30 \\
\hline L.S.D. 5\% & 75.51 & 2.49 & 4.12 \\
\hline
\end{tabular}

It should be considered that potato is ahighly absorbent crop of nutrients to the extent of luxury, so the results at this study may be related to reaching the plants to a state of nutrition balance through their various growth stages in addition to the climate conditions effect in plants (Al-Dobybi,2003). The results in tables $(1,2,3)$ perhaps can be attributed to the integration between the organic matter and calcium and that could have positive effects in growth development as shown in (table1). Foliar application of organic matter can improve the growth of plant leaves, roots and tubers by increasing plant growth processes within the leaves and stems occurs, the carbohydrates and proteins are then transported down into the tubers beside that organic matter also increasing

DOI: $10.9790 / 2380-1007020105 \quad$ www.iosrjournals.org $3 \mid$ Page


membrane permeability (Stevenson,1994). This probably explains the positive effects of treatments from organic source in vegetative growth, tubers and yield indicators. The role for organic matter is compatible with calcium control in physiological activities in the plant by stimulate a number of enzymes activity and contributing to photosynthesis and increasing its efficiency by raising $\mathrm{CO}_{2}$ assimilation in plant . Calcium is also involve in the biosynthesis of auxins which help the plant in cell division and cell elongation (AbuDahi and AlYounis,1988 ; Al-Sahaf,1989b ; Pilbeam and Moley,2006 and David,2007).This had a positive effect in the indicators of treated plant growth and the content of their tubers besides production indicators (table 3).The results concluded in this experiment were not in agreement with the results obtained by Ezzate et al. (2011) who's found that spraying with organic nutrients gave no significant effect in activity of peroxidase enzymes in potato tubers. It also notice the significant effect of spraying treatments under this experiment in activity of $\alpha$ amylase enzyme and this can be attributed to the role of calcium which associated with organic matter in stimulate the activity of enzyme (Yoon et al.,1993).This can also be due to change in the enzyme activity in accordance to the stages of tubers development and that similar finding were obtained by Sadik (2007).The reason of significant effects of spraying treatment with calcium from mineral source in the tubers content from $\mathrm{P}$ and $\mathrm{K}$ may be attributed to calcium which associated with phosphor and their physiological roles in plant. However, the increasing of potassium absorption in an efficient by calcium(AbuDahi and Al-Younis,1988) and control of phosphor on carbohydrates analysis and others products resulting from carbon assimilation (AlNiemi,1999) and being phosphor a mobile element (Sanchez,2006) probably led to increase the tubers content from potassium and phosphor.The experiment results showed clearly the importance of foliar application with calcium from organic source $\left(5\right.$ and $\left.7.5 \mathrm{ml} . \mathrm{L}^{-1}\right)$ due to their enhancement of tubers nutritional content and the total productivity of the economical outputs, furthermore, reducing the harmful effects of the environment by using safe and organic fertilizers.

\section{References}

[1] Abu Dahi,Y. and M. A. Al-Younis.1988. Plant Nutrition Evidence . Ministry of Higher Education and Scientific Researcher. Mosul University. Dar Al-Kotob for Printing and Publishing . Iraq.pp.411.

[2] Al-Ajeel, S. A. and I. A. Al-Hasnawi .2011. The effect of spraying (LIQ HUMUS) on the yield and some quality parameters of tubers potato of the two cultivars (Aladin and Burren). Kufa J. of Agric., 3(2) : 117-126.

[3] Al-Dobybi , M. H. M.2003. Effect of some minernalnutrients on qualitative, quantitative , anatomical properties and storability of potato (SolanumtuberosumL.) . Ph. D. Thesis . Horticulture Department . College of Agriculture . University of Baghdad . Iraq.

[4] Ali , N. S. 2012. Fertilizers Technology and Uses . Department of Soil and Water Sciences . Ministry of Higher Education and Scientific Researcher. University of Baghdad . Dar Al-Jameiah for Printing and Publishing . Iraq.pp.202.

[5] Al-Mharib , M. Z. 2008. Effect of foliar spray potassium and calcium and companion on growth , production and storability of potatoes (SolanumtuberosumL.). M.Sc. Thesis. HoticultureDepartment . College of Agriculture . University of Baghdad . Iraq.

[6] Al-Niemi , S. N. 1999. Fertilizer and Soil Fertility. Ministry of Higher Education and Scientific Researcher. University of Mousl . Dar Al-Kotob for Printing and Publishing .Iraq . pp.384.

[7] A. O. A. C. 1970. Association of the Official Analycial Chemistry $11^{\text {th }}$ ed. Washington D.C.

[8] Al-Sahaf , F.H. 1989 a. Plant Nutrition Practice. Ministry of Higher Education and Scientific Researcher . University of Baghdad. Dar Al-Hekma for Printing and Publishing . Iraq. pp.307.

[9] Al-Sahaf , F. H. 1989b. Cultivation Systems on Soilless. Ministry of Higher Education and Scientific Researcher. University of Baghdad . Dar Al-Hekma for Printing and Publishing . Iraq. pp.307.

[10] Boras , M. , B. Abu-Turabe and I. Al-Baset. 2011. Vegetable Crop Production . The TheoraticalPart . Damascus University Publication. College of Agriculture, Syria.pp.466.

[11] Chen , J. H.2006. The combined use of chemical and organic fertilizers and biofertilizer for crop growth and soil fertility . Department of Soil and Environmental Sciences . N. C. H. University Taaiwan.

[12] David , J. P. 2007. Handbook of Plant Nutrition .Morly Wight Salads Ltd. Arrteton . United Kingdom.

[13] 13-El-Sahooki, M. M. and K. M. Wahaib.1990. Application on Experimental Design and Analysis . Ministry of Higher Education and Scientific Researcher.University of Baghdad . Dar Al-Hukma for printing and Publishing .Iraq . pp.486.

[14] Ezzat, A. S. , H. El-S. Asfour and M. H. Tolba . 2011. Improving yield and quality of some new potato varieties in winter plantation using organic stimulators. J. Plant Production, Mansoura Univ. 2 (5):653-671.

[15] GenStat . 2013. GenStatRelease, VSN International Ltd. Rothamsted Experimental Station . UK.

[16] Harris , P. M. 1978. The Potato Crop : The Scientific Basis for Improvement . Champan\& Hall Ltd.

[17] John , M. K. 1970. Colorimetic determination of phosphorus in soil and plant materials with ascorbic acid . Soil Sci. 109:214-220.

[18] Matlob , A. N. , E. D. Sultan and K. S. Abdoul.1989. Vegetable Production.2 $2^{\text {nd }}$ Part Ed. Ministry of Higher Education and Scientific Researcher .MouslUniversity . Dar Al-Kotob for Printing and Publishing . Iraq.pp.680.

[19] Miller, G. L. 1959. Use of dinitro salicylic acid reagent for determination of reducing sugar ,Analyt. Chem. 31:426-428

[20] Nezih, M. 1985. The peroxidase enzyme activity of some vegetables and its resistance to heat, Food Agric. 36:877-880.

[21] Pilbeam , D. J. and P. S.Morley.2007. Calcium .In Barker,A. V. and Pilbeam D. J. (Eds.) .Handbook of Plant Nutrition. CRC Taylor and Francis Group, U.S.A.

[22] Priest , F. G. 1984. Extracellular Enzyme .Vanostrand Reinhold UK Cot. Ltd.

[23] Sadik, S. K. 2007. Changes in leaves and potato cv. Desiree tubers content of total phenolics, peroxidase and $\alpha$-amylase enzymes during tuber initiation and tuber development . Tikrit Univer. J. of Agric. Sci. , 7(1):171-180. 
[24] Sanchez, C. A. 2007. Phosphorus . In Barker, A. V. and Pilbeam D. J. (Eds.).Handbook of Plant Nutrition. CRC Taylor and Francis Group , U.S.A.

[25] Shtelzer, S. and S. Braun . 1994. An optical biosensoc based upon glucose oxidase immobilized in sol - gel silicate matrix. Biotech. Appl.Biochem. 19(3) : 293-405.

[26] Stevenson, F. J. 1994. Humus Chemistry : Genesis Composition Reaction $2^{\text {nd }}$ ed. Wiley , New York . U.S.A.

[27] Yoon , E. S. , S. J. Kang , B. S. Noh and E. H. Choi. 1993. Isolation and charachterization of peroxidase from Jerusalem artichoke tubers Korean J. Food Sci. Technol. 25 (5) : 565-570.

N. J. K. Al-Aamry. "The Effect of Spraying with Two Different Sources of Calcium in Vegetative Growth Characteristics and Yield of Potato." IOSR Journal of Agriculture and Veterinary Science (IOSR-JAVS) 10.7 (2017): 01-05. 